THE communication from Mr. C. J. P. Cave ${ }^{1}$ prompts me to record a somewhat similar experience. At 7.30 p.m. G.M.T. on the evening of August 3, the sky was clear except for a patch of striated cirrus cloud high up in the sky in a north-westerly direction. There suddenly appeared a band of colours right across this patch as if it were a rainbow. As the sun sank towards the horizon the band of colour moved downwards across the cloud, with an increase in the intensity of the colours. At one time part of a 'secondary' band of colour was visible, but this quickly faded as the band approached the lower edge of the cloud patch. The whole phenomenon lasted approximately fifteen minutes or so.

22 Michleham Down, Woodside Park, ERIC H. Dock. London, N.12. Sept. 8.

${ }^{2}$ Nature, 154, 240 (1944).

\section{Spectrum Formed on a Cloud}

BETwEen 8.55 and 9.00 p.m. British Summer Time on the evening of July 31 , my family and I happened to be in our garden looking towards the setting sun. "The sky was blue, broken by a few wisps of feathery cloud. When two wisps passed in turn at an elevation of roughly $60-70^{\circ}$ between us and the sun, each showed a brilliant spectrum. The colours violet, blue, green, yellow, orange and red were clearly seen, violet being on top and red below.

The colours were much more brilliant than in any rainbow we have ever seen; they were evidently projected upon the clouds and the spectrum was therefore real and not virtual. There was no sign of rain at the time and the sun was a bright red ball, hidden from us by trees.

A spectrum such as above described may not be uncommon, but none of us has observed one before.

58 Lemsford Road,
St. Albans.

E. Nightingane.

\section{Smoke and Rain}

IN a letter in Nature of August 12 (p. 213), Dr. J. R. Ashworth directs attention to the fact that the average rainfall at Rochdale on Sundays was 6 per cent below the average for weekdays during the thirty years 1898-1928, and that a similar deficit is evident if the data for the forty-five years 1898-1943 are used. It would have been interesting if he had quoted separately the figures for the latest fifteen years, 1929-43.

The average annual rainfall for each day of the week during 1929-43 can be deduced from the figures quoted in Dr. Ashworth's letter, and appear to be as follows :

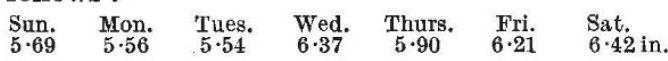

The rather large variations between different days suggest that a period of fifteen years is too short to eliminate the effect of random fluctuations in the rainfall. Nevertheless, the fact that Sunday is only the third driest day suggests that the factors which previously caused Sunday to have the lowest rain. fall have now ceased to operate.

Assuming that rainfall is increased by smoke in the atmosphere, the explanation is probably as follows: First, as Dr. Ashworth suggests, the increasing use of electric power has decreased the output of smoke from factories. Secondly, this has prob. ably been accompanied by an increased number of private houses heated by coal fires, which are lit on Sundays as well as weekdays. It therefore seems likely that smoke from domestic coal fires is now a major factor in polluting the atmosphere of urban areas.

61 Lancaster Road,

J. R. Вівву.

Carnforth, Lancs.

\section{Books : The Warehouse of Knowledge}

I HAVE read with interest and appreciation your leading article "Books: The Warehouse of Knowledge" in Nature of September 9, 1944. That article is supported by "A Reading Survey" issued by the City of Leeds Public Libraries, and a corresponding survey in technical or scientific libraries might provide even more emphatic support. There are, however, two further points which I think should be borne in mind.

(1) Not only are books of importance for general education and technical training, but also the provision of adequate text-books and monographs on special subjects is of vital importance in research.

(2) Very few technical and scientific books of this class are now being published in Great Britain. The reasons for this are fairly clear from this leading article. The seriousness of this situation is not, however, sufficiently realized. Before the War any shortcomings in the British supply of books could be rectified by the supply of German and other European books as well as American books. The supply of such books has now been reduced to almost negligible proportions under the Trading with the Enemy Regulations, and it now appears that increasing difficulties are being experienced, owing to Government regulations, in obtaining from America the supplies of scientific and technical books which our research workers require for day-to-day purposes. The Government policy with regard to paper control is only part and parcel of a policy and attitude to technical and scientific books which tends to frustrate the effect of proposals for the expansion and development of research.

Hexagon House, Blackley,

R. Brightman.

\title{
Importance of Film Records
}

RefERRING to Dr. M. Michaelis' communication in Nature of September 16, p. 365, I am, of course, well aware of the activities of the newly formed Scientific Film Association. Like the British Film Institute, however, it can only make contact with central organizations. These may or may not know what films are in existence on their particular subject.

Most scientific workers read Nature. It is to the individual maker of films that I appeal, in the hope that the learned societies may thus be persuaded to take action. Spreading the burden is preferable to allowing it to fall on the shoulders of any one organ. ization, whose judgment as to what is and what is not worthy of preservation cannot be so authoritative as that of workers in the same field.

Oltver Bect. 